Jurnal Pendidikan Bahasa Inggris Proficiency, Vol 4 No 1 Jan 2022

\title{
THE IMPLEMENTATION OF TEACHING LISTENING TOEFL AT TEST ENGLISH SCHOOL
}

\author{
Faizatul Hayati, Erwin Hari Kurniawan \\ Email : izzafaizah127@gmail.com, erwin@uniska-kediri.ac.id
}

\begin{abstract}
TOEFL test is requirement that must be done by some university, especially for English education department. From that situation, choose the right school to learn listening TOEFL. TEST English School is one of School or Course that focuses on the TOEFL preparation. This research conducted to describe the implementation of the TOEFL listening teachers at TEST English school in teaching TOEFL listening TOEFL. Descriptive qualitative method is used by this research. The data sources are the teachers of listening TOEFL, the director and 50 $\%$ students that learn listening TOEFL. Data collection technique in this research are interview, observation and documentation and three instrument there are interview guides, observation checklist and documentation. The data analysis technique in this research are reduction, data display and drawing conclusion. The result of this research are: 1) the teacher preparation in teaching listening TOEFL are syllabus, lesson plan and media, such as laptop, WhatsApp audio listening, projector, speaker, songs and Cambridge online dictionary, 2) the teachers do warming up before teaching, check the students' homework, teaching by using clear explanation, good interaction with the students, solve the students' problem, give the tips in doing the test and increase the students' listening and give motivation to the students. 3) The evaluation done in every morning by doing test or scoring and done discuss the students' problem in learning or doing the test in every Friday.
\end{abstract}

Keywords : Teaching, Listening and TOEFL.

\section{INTRODUCTION}

Teaching in the old paradigm is the process of conveying information or knowledge from teachers to students, that statement according to Asrar (2020). This paradigm implies that everything is determined by the teacher. Teachers is a center learning, the teacher is as a learning resource. The Teacher have a very important role to improve student' ability. According to Herreid ( 2006 ) the problem of having many students are attendance, dicipline and lack of motivation. Giving motivation is the teacher's job. Morover in teaching TOEFL program. Preparation is the important one for the student. This problem address because of lectures' teaching methode in TOEFL preparation. It can be conclude that teaching TOEFL need some strategies to achieve the goal.

TOEFL (Test of English as a Foreign Language) test is one of the requirements which has to be fulfilled by English education department students before getting their graduation. This policy is determined by some universities in 
Indonesia including Faculty of teacher training and education of Mataram University. It requires students to have minimum TOEFL score 500 (the score standard can be different in each university). This policy is made as an English ability standard which is believed that at this level, the students are ready to graduate, study aboard or continue study to the higher level and also for teaching. Hence, taking TOEFL test is needed for graduation.

Audio listening that is used during TOEFL learning has 3 types, namely short dialogues, long conversation and talks. According to Yuliandani (2014) found to her research entitled Analyzing Studens' TOEFL Listening Comprehension Test Performance at Tanjungpura. That research used descriptive study. The result of her research is the most difficult test in listening comprehension is short dialogue. It can be concluded that students in Tanjungpura when carrying out the TOEFL listening test experienced one difficulty out of three kinds of listening comprehension, namely short dialogue. That problem happen because the teacher had wrong strategy in teaching listening.

The students often get problems in learning listening. The problems can be internal or external. Hamaouda (2013) states that the student's problems in learning listening related to the listening text, listening problems related to the task and activities, listeners problems related to the listeners and teacher's methodology. It can be interpreted that inappropriate methods or media are one of the students' problems in improving listening skills. Wrong strategy and media were also found in Desi Surlitasari Dewi and Megawati's (2018) research. From these studies it was found that listening skills did not increase due to the teacher's inappropriate strategies in the classroom.

TOEFL test can be done online or through a direct test. To achieve the desired score. Students must learn to achieve this. learning the TOEFL materials and exercises are really needed for students. Choosing the right institution to be able to guide easily is needed by students. TEST English School is one of the institution in the English Village, Tulungrejo, Pare, Kediri, East Java. Test English School is a School dedicated to learning TOEFL and EILS materials. The uniqueness from TEST English School is the students practice do exercise in every morning. A lot of practice is needed to make it easier to do the test of TOEFL.

TEST English School is an English School in Pare Kediri that focuses on preparing for the English Language Test (TOEFL and IELTS). The test learning materials cover all English skills, ranging from oral to written communication which are divided into: listening, reading and structure. Tests dedicate themselves to students who want to successfully pass the English test with the desired score. So, the researcher interested in conducting research in following statement problem: 1) how is the preparation of teaching listening TOEFL at TEST English school, 2) how is the implementation of teaching listening TOEFL at TEST English School, 3) how is the evaluation of teaching listening TOEFL at TEST English School. The following research objectives are: 1) To describe the preparation of teaching listening TOEFL at TEST English school, 2) To describe the implementation of teaching listening TOEFL at TEST English school, 3) To describe the evaluation of teaching listening TOEFL at TEST English school. how to implementation of 
Jurnal Pendidikan Bahasa Inggris Proficiency, Vol 4 No 1 Jan 2022

teaching listening TOEFL at TEST English School. it will describe about how is the preparation, implementation and evaluation during teaching listening TOEFL.

\section{METHOD}

This research explain about the implementation of teaching listening TOEFL at Test Englisg School. It explaine by using descriptive qualitative research. Descriptive research aims to accurately and systematically describe a population, situation or phenomenon. It can answer what, when, where, when and how questions, but not why questions. It can be identified characteristics, frequencies, trends, correlations, and categories. It is useful when not much is known yet about the topic or problem. Before the researcher know why something happens, the researcher need to understand how, when and where it happens.

The setting of this research conducted at TEST English School. The School is located at Yos Sudarso Street Kampung Inggris, Tulungrejo, Pare, Kediri. Test English School is some English School in Kampung Inggris which has many programs. Collaboration program, home schooling (3months), preschool (2 months), IELTS camp (2 months), TOEFL camp (1 month).

According to Marshall (2006) "Qualitative research has four methods for gathering information. They are participating in the setting, observing directly, interviewing in depth, and analyzing documents and material culture. Observing directly, interviewing in depth and analyzing document material are used in this research. Observation was used to get information about the teachers' implementation of teaching listening TOEFL. Interview was used to get the information from the director, students, and the tutor which is teaching listening TOEFL. Documentation was used to get information that related with listening TOEFL, such as as picture, voice record, lesson plan, syllabus and the teaching media, used by the teacher.

This research requires some data. the data is obtained from several things that can help researchers get data during research. Data source is divided into two types, they are primary data and secondary data. Listening TOEFL teacher is the primary data source from this research because these teachers are very knowledgeable about the teaching process in the classroom. Director TOEFL is the second primary data in this study. Director is someone who has a very high position. Before the learning is carried out, all matters related to learning must be approved by the director. In addition, The researcher used student as the data source. The data will be obtained by conducting interviews with three students who are studying.

After collecting the data, the researcher analyzes the data. Data analysis in qualitative research is defined as the process of systematically searching and arranging the interview transcripts, observation notes, or other non-textual materials that the researcher accumulates to increase the understanding of the phenomenon. There are three steps of analyze data in descriptive qualitative, those are reduction, data display, and drawing conclusion. Reduction is the process of selecting, identifying, classifying, and encoding data. Data display is the process of data simplification. Drawing conclusion is the output of the results of the analyzed data. 
Jurnal Pendidikan Bahasa Inggris Proficiency, Vol 4 No 1 Jan 2022

\section{RESULTS AND DISCUSSIONS}

Results and discussions focused on the research focus. There are: 1) the preparation of teaching listening TOEFL at TEST English School, 2) the implementation of teaching listening TOEFL at TEST English School, 3) the evaluation of teaching listening TOEFL at TEST English School.

\section{1) The Preparation of Teaching Listening TOEFL at TEST English School}

Teaching toefl need more preparation. Every teacher has their own way of preparing to teach. Such as preparing the material that will be given to students or the media that will be used in teaching students.

\section{a. Syllabus}

The first thing that should prepare before teaching is syllabus. The coordinator of TOEFL program made the syllabus before beginning the program. The coordinator of TOEFL program at TEST ENGLISH SCHOOL is Mr. Pandri. $\mathrm{He}$ is the coordinator of TOEFL program and TOEFL's teacher. According to the result of interview, he said that he arrange the materi from the easier to the most difficult material. The material taken from Longman, ETS and ultimate. The students get a module for learning and exercise the listening of TOEFL. Besides syllabus, the tutor's preparation according to the interview from the teacher of listening TOEFL at TEST English School did some preparation before teaching.

\section{b. Media}

From the results of observations and interviews, media is a very important material for teachers in teaching. In addition to preparing materials and how to teach listening, tutors have also prepared media that will be used in teaching such as sound systems, WhatsApp, projectors, laptops, audio listening, songs and dictionaries that will be used in checking session if students are confused with the material. The song is used for warming up. The next media used are laptops, projectors, audio listening, and sound systems. The results of the observations showed that the tutor opened the dictionary using a laptop and a projector screen. So all the students see the dictionary through the projector. Students listen to audio listening through a sound system that has been prepared in class.

According to the results of the data obtained through interviews, observation and documentation, the teacher prepares two things before teaching. Namely syllabus and media. Tutors make syllabus by arranging material from easiest to hardest. The material was taken from three sources, namely Longman, ETS and Ultimate. The media prepared before teaching were songs, laptops, sound system, projectors, online Cambridge dictionaries, TOEFL audio listening and WhatsApp.

\section{2) Implementation of Teaching Listening TOEFL at TEST English School}

Teaching TOEFL listening requires several strategies to achieve the goal. Students studying on the TEST English School have very high goals because their goal is to get a scholarship or want to go abroad. So to achieve this goal, their schedule is made as tight as possible so they become more focused. So the teachers, must have their own strategy in teaching. This statement is evidenced by the data 
Jurnal Pendidikan Bahasa Inggris Proficiency, Vol 4 No 1 Jan 2022

obtained at the time of observation and interview of 6 students. The results of the interviews from the 6 students had the same answer.

\section{a. Pre Teaching}

From the observations, the teacher started the lesson by greeting and playing 3 songs as warming up. This right is supported by a statement from the TOEFL listening tutors. After playing the songs the teacher giving assignments and check it. The teachers give assignments to the students every day. The assignment is their ticket to join the class. It can be proven from the result of students' interview.

Based on to the result of interview and observation, it can be conclude the teacher open the class by greeting than play song as warming up and checking the students' homework as the ticket for joining the lesson.

\section{b. While Teaching}

After checking the homework, the teacher asked the students to open the book and the teacher explained the material in the book. The results of observations show that in explaining the material the teacher always pays attention to the problems faced by students in order to solve these problems. The difficulty experienced by teachers when teaching is when students do not have good English knowledge. These difficulties often occur and teachers must be able to overcome students' difficulties in learning listening.

Some teachers make a rule in the class to make the learning and teaching process conducive and run well. So, the students must obey the role. But according to the result of interview, there is no big rules in the teaching-learning process. From the result of interviews and observations it can be conclude that the teachers have good interaction with the students. The teacher explain the material clearly and always solve the students' problem. The role in the class just do not allow the student to eat meal. The teacher always give them tips to increase their listening.

\section{c. Post Teaching}

According to the results of observations. The teacher closes the lesson by asking students' understanding. Whether students have understood or not. If students have questions, the teacher answers the questions. Before closing the lesson, the teacher motivates students to do listening exercises as often as possible. Because good listening is because they are used to listening.

\section{3) The Evaluation of Teaching Listening TOEFL at TEST English School}

Evaluation plays an enormous role in the teaching-learning process. It helps teachers and learners to improve teaching and learning. According to the result of interview and observation show that the students do the scoring or practice every morning. According to the result of interview and observation. TEST English School does 2 evaluation. The first is done every morning and the second is done every Friday at the second week. From the result of interview, observation and documentation, evaluation does in two types. The teachers try to solve the students' problem in learning and doing the test of Listening TOEFL in every Friday and the 
Jurnal Pendidikan Bahasa Inggris Proficiency, Vol 4 No 1 Jan 2022

students do scoring every day. TEST English School use ITP rules in implementing the scoring.

\section{CONCLUSION}

According to the results of the data conducted by interview, observation and documentation regarding the implementation of teaching listening TOEFL at TEST English School, Three conclusions can be drawn as follows: 1) the teacher preparation in teaching listening TOEFL are syllabus, lesson plan and media, such as laptop, audio listening, projector, speaker, songs and Cambridge online dictionary; 2) the teachers do warming up before teaching, check the students' homework, teaching by using clear explanation, good interaction with the students, solve the students' problem, give the tips in doing the test and increase the students' listening and give motivation to the students; and 3) the evaluation done in every morning by doing test or scoring and done discuss the students' problem in learning or doing the test in every Friday.

From the conclusion of this research, the researcher can make some suggestions. For the teachers, the teacher who makes the syllabus should use a theoretical basis so that it is structured correctly. The teachers should show the syllabus and lesson plans to students at the first meeting. The syllabus should make by all of teacher. The teacher should review the material before continuing to the next lesson. During the practice session in class, the teacher should check again to make sure that the students' answers are correct. For the further researchers, this research hope that future researchers will look for references in depth about the theory in teaching TOEFL listening. It also hopefully for the further researcher to make as many observations as possible until the data obtained is saturated and conduct interviews as much as $50 \%$ of the total number of students.

\section{REFERENCES}

Bozorgian, H.(2012). The relationship between listening and other language skills in the international English language testing system. Theory and Practice in Language Studies, 2(4): 657-663.

Bergman, O. (1999). Wait for me! Reader control of narration rate in talking books. International Reading Association's Reading Online. Retrieved February 2, 2009, from www.readingordine.arg / articles /art_index.asp?HREF=bergman/index.html

Raini, P. Y. (2014). Analayzing Stusents's TOEFL Listening Comprehension Test Performance. Journal of Equatorial Education and Learning.

Gonulal, T. (2020). Improving Listening Skills with Extensive Listening Using Podcasts and Vodcasts. International Journal of Contemporary Educational Research, 7(1): 311-320. DOI: https: //doi.org/10.33200/ijcer.685196.

Khalid, I. Al-Nafisah. (2019). Issues and Strategies in Improving Listening Comprehension in a Classroom. International Journal of Linguistics. Macrothink Institutetm.

Darti, A. A. (2017). Analyzing Students's Difficulties Toward Listening Comprehension. 
Jurnal Pendidikan Bahasa Inggris Proficiency, Vol 4 No 1 Jan 2022

Nurhayati \& Kurnia, I. (2011). Correlation Between Listening Comprehension and Speaking Ability.

Desi, S. D., \& Megawati. (2018). A study on the Relationship between Student's listening Anxiety and Listening Comprehension. Anglo-Saxon, 9(1): 100-106.

Yusnida, D., et al.(2017). A Study of Teaching Listening. ENGLISH EDUCATION JOURNAL (EEJ), 8(4): 439-456, October 2017.

Abdul, W. K., \& Qona'atun, A. (2020). English Teacher' Strategy in Teaching Listening Section of TOEFL Preparation. Journal of English Language Teaching and Literature, 3(2), August 2020.

Walker, N. (2014). Listening: The Most Difficult Skill to Teach. Encuentro 23, 2014, ISSN 1989-0796:167-175.

Assoc. Prof. Ekrem SOLAK. (2016). Teaching Language Skills for Prospective English Teachers.

Regulation Minister of National Education Republic of Indonesia. (2007). Process Standards for Primary and Secondary Education Units. Minister of National Education Number 412007.

ETS TOEFL. (2020). TOEFL ITP. www.ets.org.

Willis, J. 1981: Teaching English Through English. London. Longman 